\title{
Chicken cecal DNA methylome alteration in the response to Salmonella enterica serovar Enteritidis inoculation
}

\author{
Yuanmei Wang ${ }^{1 \dagger}$, Liying Liü ${ }^{2+}$, Min Li ${ }^{1}$, Lili Lin ${ }^{1}$, Pengcheng Su${ }^{1}$, Hui Tang ${ }^{1}$, Xinzhong Fan ${ }^{1}$ and Xianyao Li ${ }^{1 *}$ (D)
}

\begin{abstract}
Background: Salmonella enterica serovar Enteritidis (SE) is one of the pathogenic bacteria, which affects poultry production and poses a severe threat to public health. Chicken meat and eggs are the main sources of human salmonellosis. DNA methylation is involved in regulatory processes including gene expression, chromatin structure and genomic imprinting. To understand the methylation regulation in the response to SE inoculation in chicken, the genome-wide DNA methylation profile following SE inoculation was analyzed through whole-genome bisulfite sequencing in the current study.

Results: There were 185,362,463 clean reads and 126,098,724 unique reads in the control group, and 180,530,750 clean reads and 126,782,896 unique reads in the inoculated group. The methylation density in the gene body was higher than that in the upstream and downstream regions of the gene. There were 8946 differentially methylated genes (3639 hypo-methylated genes, 5307 hyper-methylated genes) obtained between inoculated and control groups. Methylated genes were mainly enriched in immune-related Gene Ontology (GO) terms and metabolic process terms. Cytokine-cytokine receptor interaction, TGF-beta signaling pathway, FoxO signaling pathway, Wnt signaling pathway and several metabolism-related pathways were significantly enriched. The density of differentially methylated cytosines in miRNAs was the highest. HOX genes were widely methylated.

Conclusions: The genome-wide DNA methylation profile in the response to SE inoculation in chicken was analyzed. SE inoculation promoted the DNA methylation in the chicken cecum and caused methylation alteration in immune- and metabolic- related genes. Wnt signal pathway, miRNAs and HOX gene family may play crucial roles in the methylation regulation of SE inoculation in chicken. The findings herein will deepen the understanding of epigenetic regulation in the response to SE inoculation in chicken.
\end{abstract}

Keywords: Chicken, DNA methylation, Cecum, Salmonella enterica serovar Enteritidis, Whole-genome bisulfite sequencing

\footnotetext{
* Correspondence: xyli@sdau.edu.cn

†Yuanmei Wang and Liying Liu contributed equally to this work.

${ }^{1}$ College of Animal Science and Technology, Shandong Provincial Key

Laboratory of Animal Biotechnology and Disease Control and Prevention,

Shandong Agricultural University, Tai'an 271018, Shandong, China

Full list of author information is available at the end of the article
}

(c) The Author(s). 2020 Open Access This article is licensed under a Creative Commons Attribution 4.0 International License, which permits use, sharing, adaptation, distribution and reproduction in any medium or format, as long as you give appropriate credit to the original author(s) and the source, provide a link to the Creative Commons licence, and indicate if changes were made. The images or other third party material in this article are included in the article's Creative Commons licence, unless indicated otherwise in a credit line to the material. If material is not included in the article's Creative Commons licence and your intended use is not permitted by statutory regulation or exceeds the permitted use, you will need to obtain permission directly from the copyright holder. To view a copy of this licence, visit http://creativecommons.org/licenses/by/4.0/ The Creative Commons Public Domain Dedication waiver (http://creativecommons.org/publicdomain/zero/1.0/) applies to the data made available in this article, unless otherwise stated in a credit line to the data. 


\section{Background}

Salmonellosis, mainly caused by Salmonella, is one of the most frequent infectious foodborne diseases around the world. Salmonella enterica serovar Enteritidis (SE) is one of the pathogenic bacteria, which causes significant economic losses on poultry production and puts severe threat on human health [1-3] through contaminated poultry and egg [4-6]. It is estimated that Salmonella enteritidis causes 1.3 million cases of gastroenteritis, and more than 350 died each year in the United States [7]. In Europe, 96,039 salmonellosis cases were reported in 2016 [8]. Effective prevention of SE infection in poultry production has aroused public attention.

DNA methylation, one of the major epigenetic modifications, is involved in the regulatory processes including gene expression, chromatin structure, genomic imprinting, transposon silencing, $\mathrm{X}$-chromosome inactivation, disease response and individual development [9-11]. DNA methylation in gene body interferes with transcript elongation [12-14], and DNA methylation of the first exon is tightly linked to transcriptional silencing [15, 16]. It has been reported that SE infection would alter expression of mRNAs and microRNAs in chicken [1720]. However, little is known about how the methylation regulates the SE inoculation.

Genome-wide DNA methylation can uncover epigenetic modification changed with animal development, evolution and environmental adaptation [21-25]. DNA methylation has been reported in many species such as human [26], bovine [21], soybean [27], rat [28], rice [29] and chicken [30]. Aberrant DNA methylation is associated with several immune deficiencies and autoimmune disorders in human [31]. The potential role of DNA methylation in regulating disease resistance in chickens has been reported through analyzing genes within the differentially methylated regions (DMR) between Fayoumi and Leghorn chicken [25]. Functional DNA methylated loci play important roles in regulating expression of genes involved in the inflammatory response and tissue injury after Avian pathogenic Escherichia coli infection in chicken [32]. Different methylation level of ANKIB1, GABARAPL1, KDM1B and DYNLRB2 genes have been detected in chicken following Salmonella infection [33]. Genes of TLR2A, TLR21, IL-8, IL2RB and ILIRAPL1 are significantly methylated after Escherichia coli infection in chicken $[32,34]$. The TLR4 methylation is related to expression of genes involved in the MyD88 signaling pathway in $S$. enteritidis susceptible DaHeng S03 chicken line [35]. Our previous results showed that SE infection repressed overall genomic DNA methylation level in Shouguang chicken through Methylated DNA quantification kit [36]. While, genome-wide DNA methylation variation of chickens infected with Salmonella is not fully clarified.
Whole-genome bisulfite sequencing (WGBS) [37] has been widely used in studies of DNA methylation associated with growth [38], development [39] and disease [40]. The cecum is the primary colonization site of Salmonella [1]. The aim of the current study was to investigate the global DNA methylation profiles in the chicken cecum and to identify potentially functional methylated regions and genes related to host response to SE inoculation through WGBS.

\section{Results}

Analysis of genome-wide DNA methylation data

One genomic DNA library was constructed in each of control and inoculated groups. There were 185,362,463 and 180,530,750 clean reads obtained from control and inoculated group, respectively (Table 1). 126,098,724 and $126,782,896$ reads were uniquely mapped to the reference chicken genome (Gallus gallus-5.0) in control and inoculated groups (Table 1). The coverage analysis revealed that approximately $81 \%$ of the chicken genome was covered by reads at least 1 -fold, nearly $77 \%$ of genome was covered by more than 5 -fold and $55 \%$ of genome was covered more than 10-fold (Table 2). In addition, 205,500,619 and 215,922,395 methylated cytosines were detected from control and inoculated group, respectively (Table 3 ).

The number of methylated cytosines in each type of $\mathrm{mCHG}, \mathrm{mCHH}$, and $\mathrm{mCpG}$ was counted and the ratio was calculated (Table 3). There were 153,870,946 mCpG sites, 37,592,584 $\mathrm{mCHH}$ sites and 14,037,071 $\mathrm{mCHG}$ sites accounting for $55.20 \%$ (mCpG/CpG), $1.00 \%$ $(\mathrm{mCHH} / \mathrm{CHH})$ and $1.00 \%$ (mCHG/CHG) identified in the control group. 167,840,943 mCpG sites, 35,035,989 $\mathrm{mCHH}$ sites and 13,045,463 mCHG sites accounting for $55.20 \%$ (mCpG/CpG), $0.82 \%(\mathrm{mCHH} / \mathrm{CHH})$ and $0.90 \%$ (mCHG/CHG) were identified in the inoculated group. Furthermore, CAG was dominant in $\mathrm{mCHG}$ type. $\mathrm{CAH}$ and $\mathrm{CHT}$ were preferred in the $\mathrm{mCHH}$ type (Fig. 1).

\section{DNA methylation in different gene regions}

To better understand methylation pattern in the genome, the methylation in different gene regions was analyzed (Fig. 2). The promoter region (the $2 \mathrm{~kb}$ bases upstream from the transcription start site (TSS)) had the lower methylation level. TSS had the lowest methylation level. The level of DNA methylation in the first exon was the lowest across all exons, but higher than that in introns. In general, the methylation density in gene body was higher than that in the upstream and downstream of the gene.

\section{Differentially methylated cytosines (DMC) in different genes}

DMC was analyzed through MOBAS according to the binomial distribution combined with the bayesian 
Table 1 Data generated by whole genome bisulfite sequencing

\begin{tabular}{lllllll}
\hline Sample & Clean reads & Clean Base & Unique mapped reads & Mapped (\%) & Conversion rate (\%) & GC(\%) \\
\hline Control & $185,362,463$ & $55,494,074,424$ & $126,098,724$ & 68.03 & 99.04 & 23.59 \\
Inoculated & $180,530,750$ & $54,074,103,970$ & $126,782,896$ & 70.23 & 99.25 & 23.12
\end{tabular}

algorithm. The distribution of DMCs in different chromosomes was shown in Fig. 3. The density of DMC located in Chr1-3 was lower than that in Chr5-30. And the density of DMC in Chr W and Z was the lowest. The density of miRNAs was higher than other genes. There were 457 miRNAs in the top 1000 genes with higher DMC density, 324 miRNAs in the top 500 genes. Gga-miR-7466, gga-mir-1713, gga-mir-1699, gga-mir7467, gga-mir-6616 had the highest methylation density (Supplementary file: Table S1). The HOX gene family was widely methylated and mainly distributed in Chr2 and 7 (Supplementary file: Table S2).

\section{Identification of differentially methylated region (DMR) and differentially methylated genes (DMG)}

There were $82.5 \%$ DMR located in the distal intergenic region, only $0.02 \%$ in the 1 st intron (Fig. 4). The DMR coverage ratio on each chromosome was calculated. The coverage ratio on Chr1, 2, 3, 16, 25, 31, 32, 33, Z and W was less than $0.5 \%$, ratio on Chr4, 5, 6, 7, 8, 11, 22, 30, 31 was between 0.5 and $0.8 \%$ and the ratio on Chr9-28 excluding for Chr11, 16, 22 and 25 was more than $0.8 \%$. Also, the ratio on Chr16, Z and W were the lowest ones with $0.07,0.01$ and $0.002 \%$, respectively. The ratio on Chr23, 24 and 26 were the highest ones with 1.10, 1.18 and $1.22 \%$, respectively (Fig. 5).

There were 8946 differentially methylated genes identified, including 3639 hypo-methylated genes and 5307 hyper-methylated genes in the inoculated group compared with the control group. Differentially methylated genes distributed variously across all chromosomes (Fig. 6). There were more than 1000 differentially methylated genes in Chr1, 500-1000 differentially methylated genes in Chr2, 3, 4 and 5, 100-500 differentially methylated genes in the Chr6-28 excluding Chr16, 22, 24 and 25, 10-100 differentially methylated genes in Chr22, 24, 25,33 and Z. Number of differentially methylated genes in Chr16, 32 and W was less than 10. More hypermethylated genes were identified than hypo-methylated genes on all chromosomes except for Chr16 and W.

Table 2 Coverage ratio of sequencing data

\begin{tabular}{llll}
\hline Sample ID & Cov_ratio_1X(\%) & Cov_ratio_5X(\%) & Cov_ratio_10X(\%) \\
\hline Control & 81.37 & 71.98 & 55.34 \\
Inoculated & 81.41 & 73.27 & 59.20
\end{tabular}

Cov_ratio: the percentage of base count in a given depth in total bases

\section{COG function classification of differentially methylated genes}

The COG (Clusters of Orthologous Groups) function classification results showed that the DMGs were mainly associated with seven categories: general function prediction only, signal transduction mechanisms, transcription, replication, recombination and repair, posttranslational modification, protein turnover, chaperones, amino acid transport and metabolism and inorganic ion transport and metabolism with a percentage of $39.56,16.12,15.48,14.51,7.65,6.18$ and $5.79 \%$, respectively (Fig. 7).

Functional annotation of differentially methylated genes To understand the function of those differentially methylated genes, Gene Ontology (GO) and KEGG pathway enrichment were analyzed. Of 8946 DMGs, 7362 genes were annotated. The results of BP (biological processes), MF (molecular functions), and CC (cellular components) were shown in Fig. 8. For the BP, the DMGs were mainly associated with immune system process, metabolic process, reproductive process, signaling, multicellular organismal process, developmental process, hormone secretion, rhythmic process, response to stimulus, biological regulation and cell aggregation. There were $54.34 \%$ (263/484) of methylated genes mapped to immune system process and 50.74\% (2241/4417) of methylated genes mapped to metabolic process (Supplementary file: Table S3). In term of the CC, the DMGs were mainly located in the extracellular region, cell, nucleoid, organelle part, virion part and membrane part. For the MF, the DMGs were associated with molecular transducer activity, receptor activity, nucleic acid binding transcription factor activity, guanyl-nucleotide exchange factor activity and chemoattractant activity.

There were 16 KEGG pathways associated with DMGs significantly enriched $(P<0.05)$. The enriched pathways were roughly grouped into three groups: 1 ) immunerelated pathways including Cytokine-cytokine receptor interaction, TGF-beta signaling pathway, FoxO signaling pathway, MAPK signaling pathway and Wnt signaling pathway; 2) metabolism-related pathways including mTOR signaling pathway, other types of O-glycan biosynthesis, inositol phosphate metabolism, Glycosphigolipid biosynthesis-lacto and neolacto series, Alanine, aspartate and glutamate metabolism, Mucin type OGlycan biosynthesis, and Glycosaminoglycan biosynthesis-heparan sulfate/heparin, Melanogenesis; 3) 
Table 3 Number and ratio of different types of methylated sites

\begin{tabular}{lllll}
\hline Group & mCHG & mCHH & mCpG & Total mC \\
\hline Control & $14,037,071(1.00 \%)$ & $37,592,584(1.00 \%)$ & $153,870,964(55.20 \%)$ & $205,500,619$ \\
Inoculated & $13,045,463(0.90 \%)$ & $35,035,989(0.82 \%)$ & $167,840,943(55.20 \%)$ & $215,922,395$
\end{tabular}

*H $=\mathrm{A} / \mathrm{T} / \mathrm{G}$

others including Progesterone-mediated oocyte maturation, adherents junction, vascular smooth muscle contraction, neuroactive ligand-receptor interaction (Fig. 9). There were 92, 80 and 98 DMGs associated with Wnt signaling pathway, FoxO signaling pathway, and Cytokine-cytokine receptor interaction, respectively. Genes in Wnt family like WNT5B, WNT2 and MYC were involved in Wnt signaling pathway. CCL4, IL-5, IL6, $I L-21$ and $I L-22$ were involved in the pathway of Cytokine-cytokine receptor interaction (Supplementary file: Table S4).

\section{Validation of DMGs through bisulfite sequencing PCR (BSP)}

To validate the sequencing results, six DMGs of HOXA3, HOXD12, DNAH7, NPAT, MTR and ZFHX3 were randomly selected. The loci in Chr2:32659632, Chr7:9749766, Chr1:180358709 and Chr1:180358843 were hypo-methylated, while loci in Chr2:32659658, Chr7:9750310 and Chr1:180358844 were hyper- methylated (Table 4). The methylation level detected using BSP method was consistent with that in WGBS results.

\section{Discussion}

The DNA methylation mainly occurred in CG context but rarely in non-CG ( $\mathrm{CHG}$ and $\mathrm{CHH}$ ) context on all chromosomes or genome functional regions of chicken, which was consistent with the DNA methylation profile in mammals [41]. It has been reported that hypomethylation in promoter and hyper-methylation in gene body could affect transcription positively. The methylation in the promoter generally induces transcription repression [42]. In the current study, DNA methylation level in the gene body was higher than that in the gene initiation and gene termination regions, which was consistent with the previous results $[43,44]$. The collective results suggest the methylation in the gene body regions may play an important role in regulating gene expression.

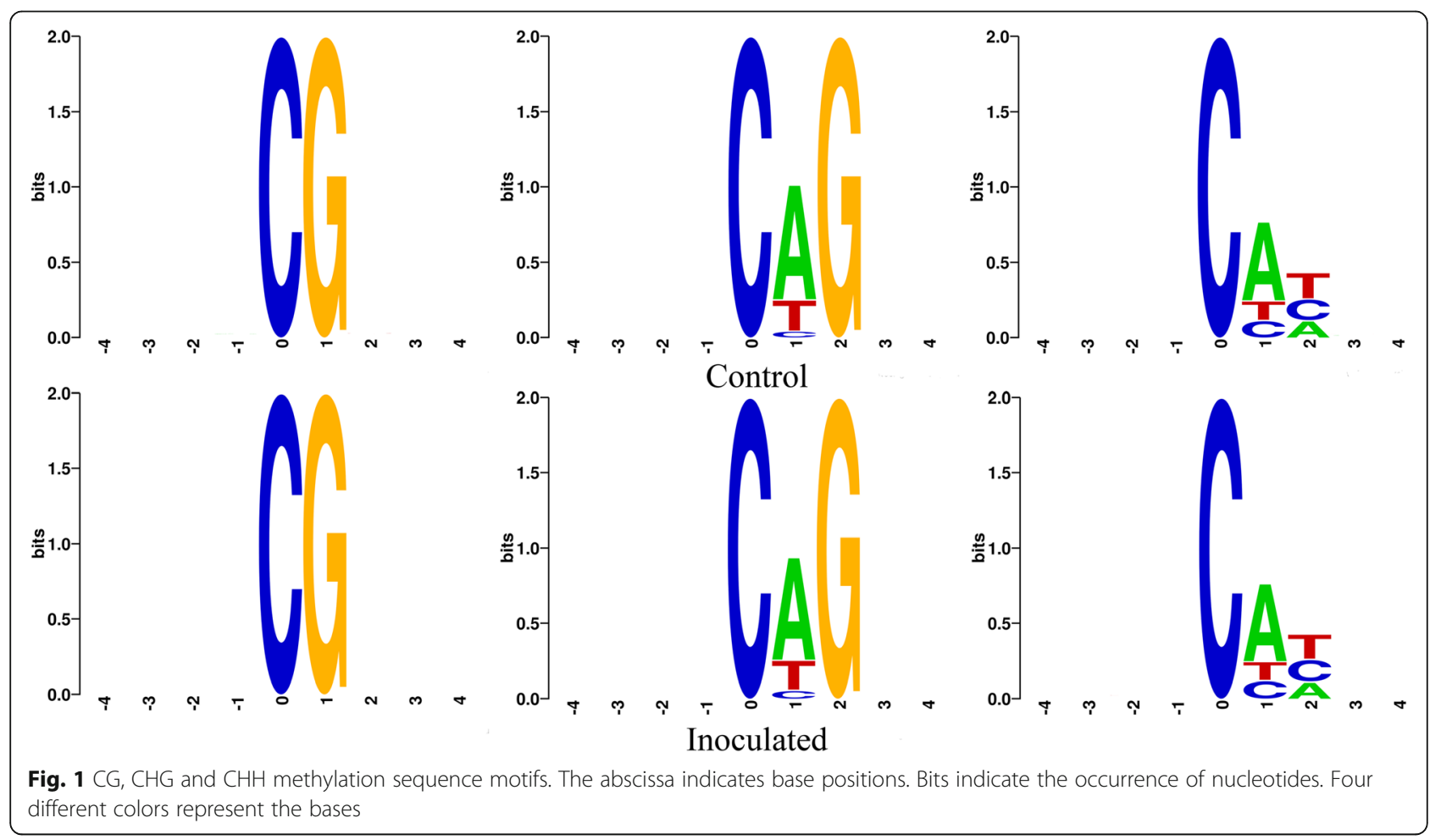




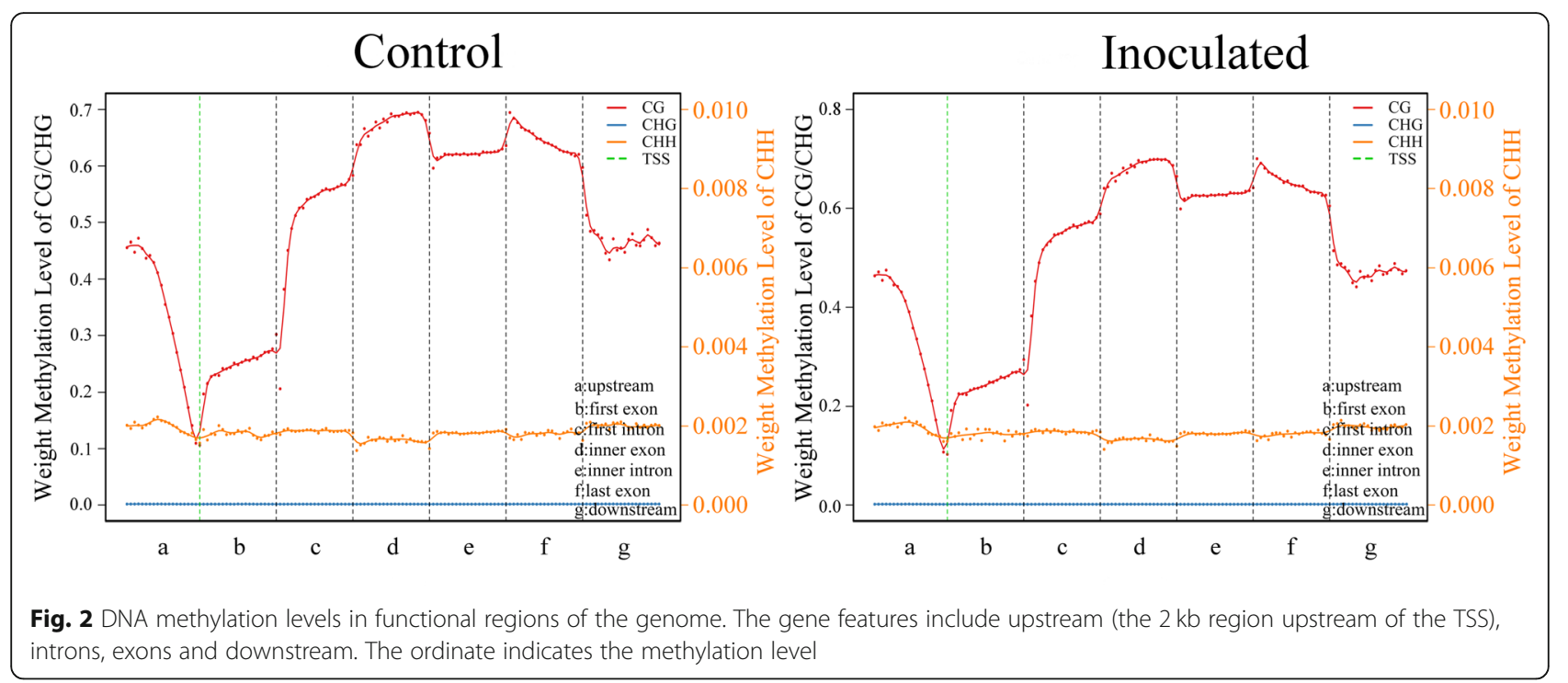

Fig. 2 DNA methylation levels in functional regions of the genome. The gene features include upstream (the $2 \mathrm{~kb}$ region upstream of the TSS), introns, exons and downstream. The ordinate indicates the methylation level

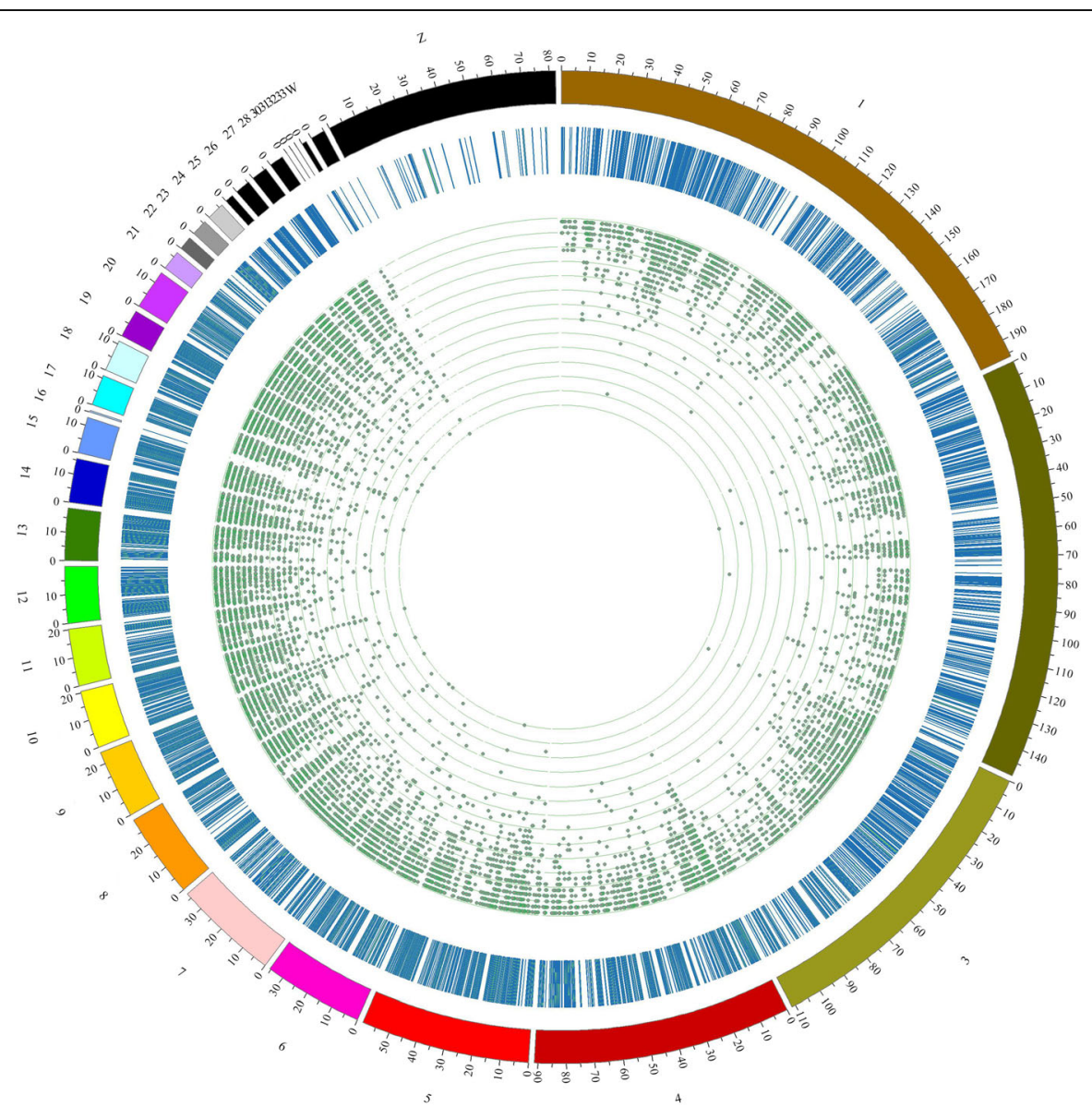

Fig. 3 Distribution of significantly differentially methylated cytosines (DMCs) on the chicken chromosomes. The top 10\% differentially methylated cytosines are represented. From the center, the first circos depicts the differentially methylated sites (green spot). The second circos illustrates the methylation density. The third circos shows the chromosomes. Chromosome name and scale are indicated on the outer rim. The closer the site in the first circle are to the center, the greater the number of DMC 


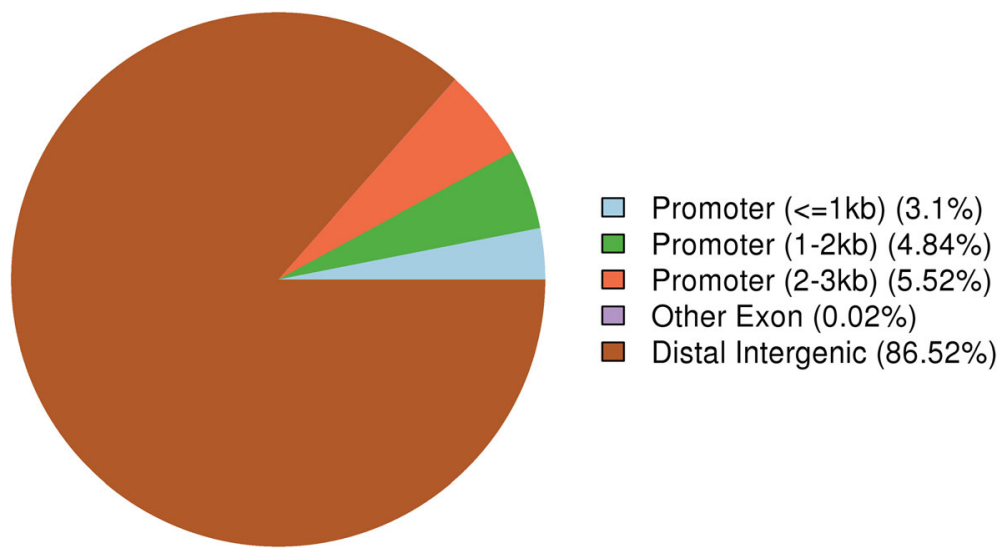

Fig. 4 The distribution of DMR in different genes. Different color is different location, the promoter is the 2000 bp of upstream in gene

The number of hyper-methylated genes in the inoculated group was higher than that of hypo-methylated genes across all chromosomes rather than Chr16 and W. It suggested that SE inoculation promoted DNA methylation in chicken and distributed unevenly across chromosomes, which was inconsistent with our previous results [36]. Different genetic background probably contributes to the inconsistent results. Previous studies in human [45] and plant [46] shows that individuals with a higher DNA methylation level in some special genes are susceptible to diseases or bacterial infection. It has been reported that the methylated genes related to Marek's disease virus infection in chicken are associated with response to stimulus, cell adhesion, and immune system process function [47]. Previous studies verifies that the immune and metabolism-related process are related with abiotic stress [48, 49] and various disease [19, 24, 50, 51]. In the current study, DMGs were mainly involved in metabolism process and immune system process, which was consistent with those previous results. It has been suggested that mechanism of disease resistance is determined by DNA methylation, and methylation variation is both a cause and consequence of viral infection [52]. Variation in the methylation state of inflammatory bowel disease (IBD)-associated genes alters gene expression, contributing to disease onset and progression [53]. The results collectively suggested that DNA methylation could regulate host immune response via regulating

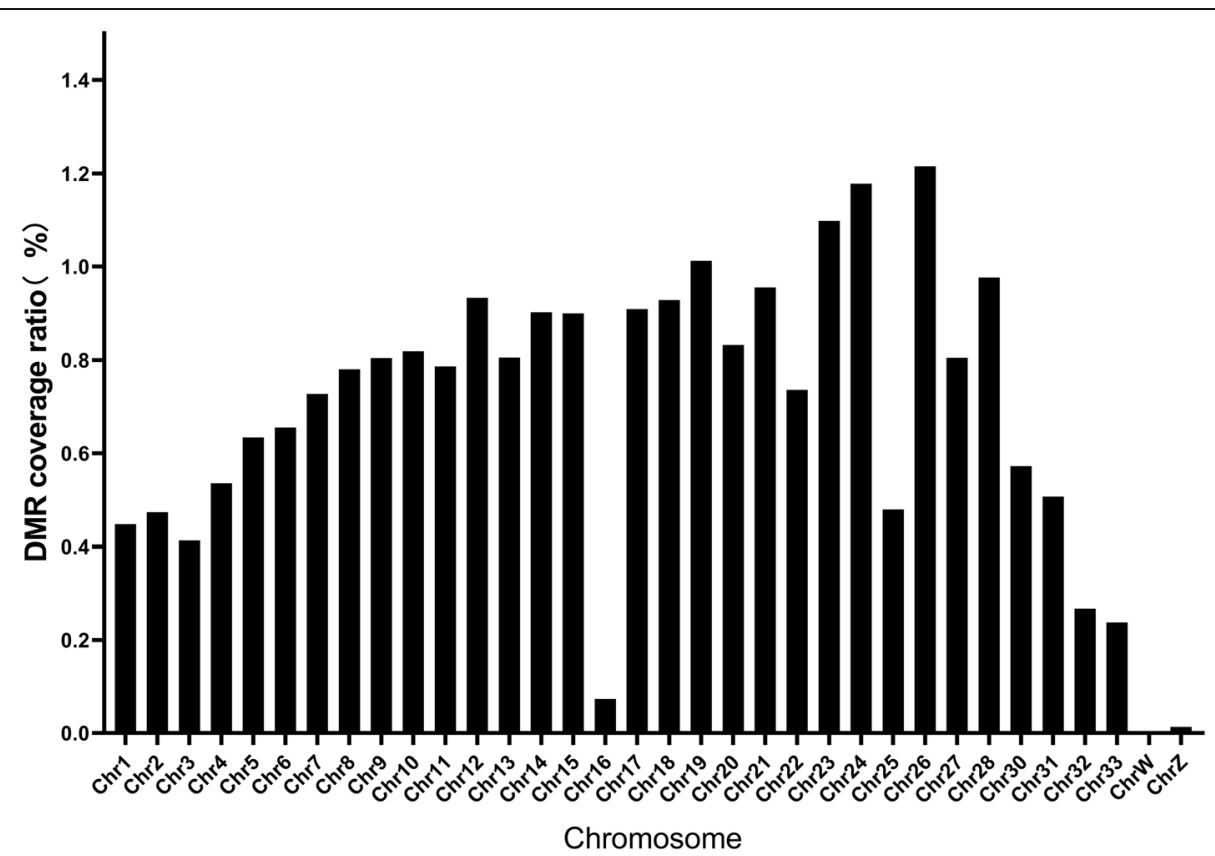

Fig. 5 The proportion of DMR in each chromosome length 


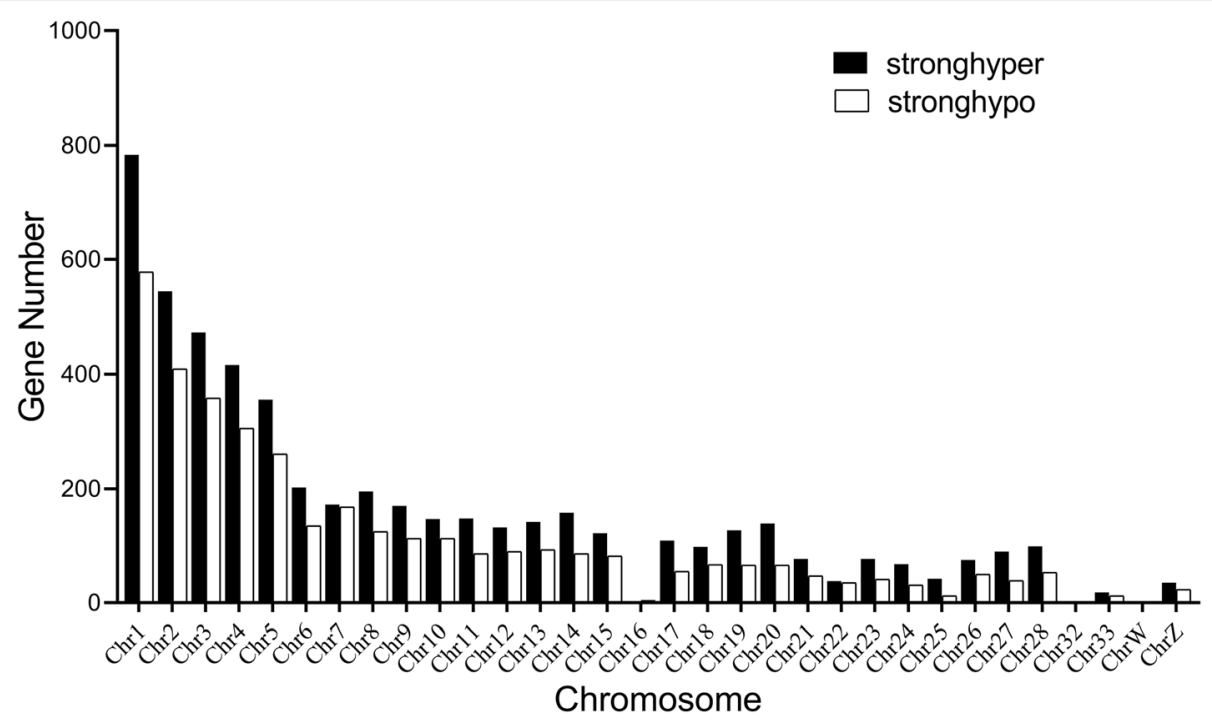

Fig. 6 The distribution of hyper- and hypo-methylated genes in each chromosome

expression of immune-related genes in response to $\mathrm{SE}$ infection.

Rhythmic process plays a dominant role in determining overall health and physiological homeostasis and could facilitate the organism to survive well in different circumstances. There was a direct molecular link existed between circadian dysregulation and diseases [54]. It has been revealed that circadian rhythm related genes play critical roles in the host response to $C$. jejuni colonization in chicken [50]. The circadian rhythm associated genes were not enriched following SE infection [20]. While, the circadian rhythm-associated circRNAs

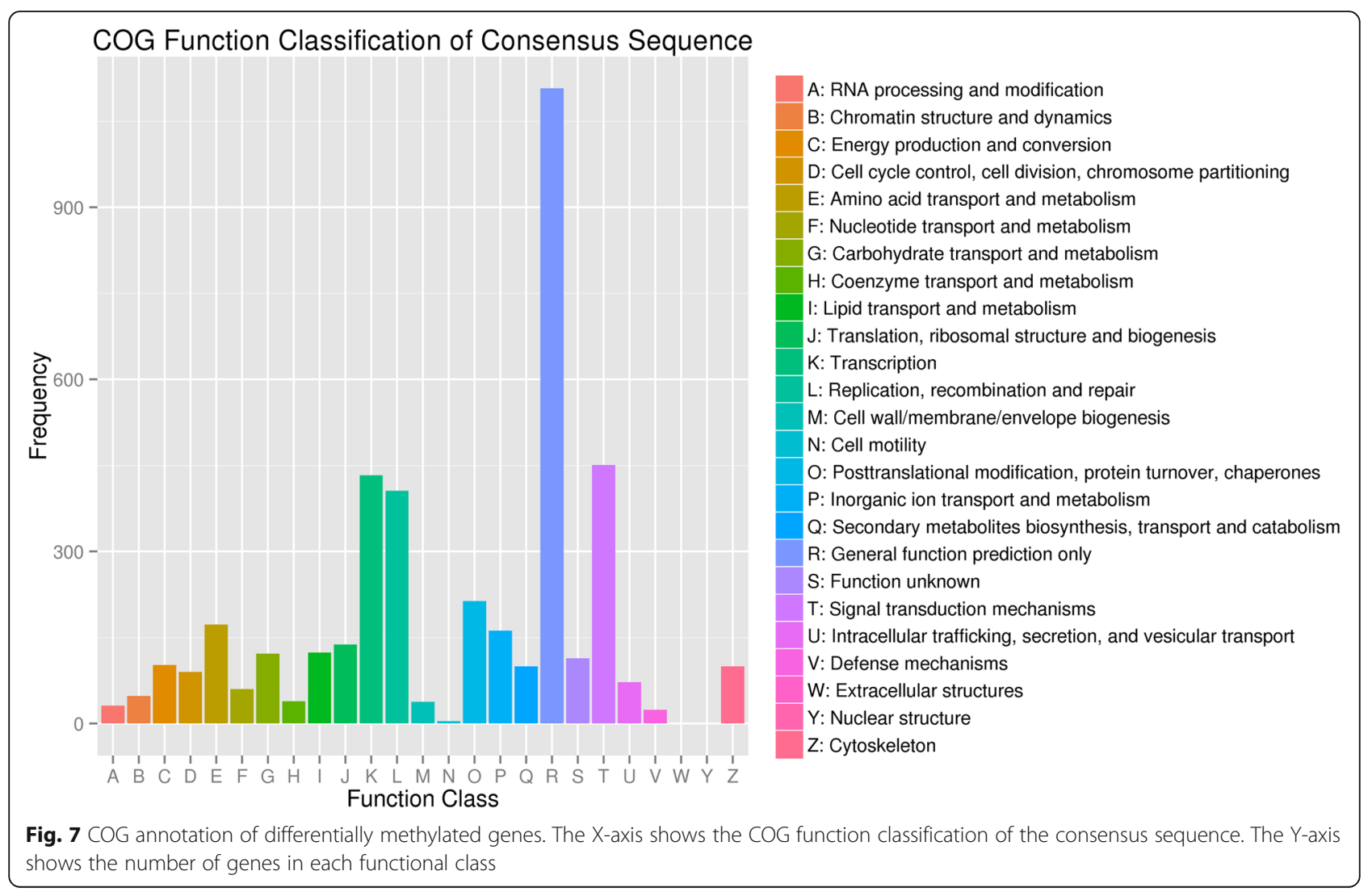




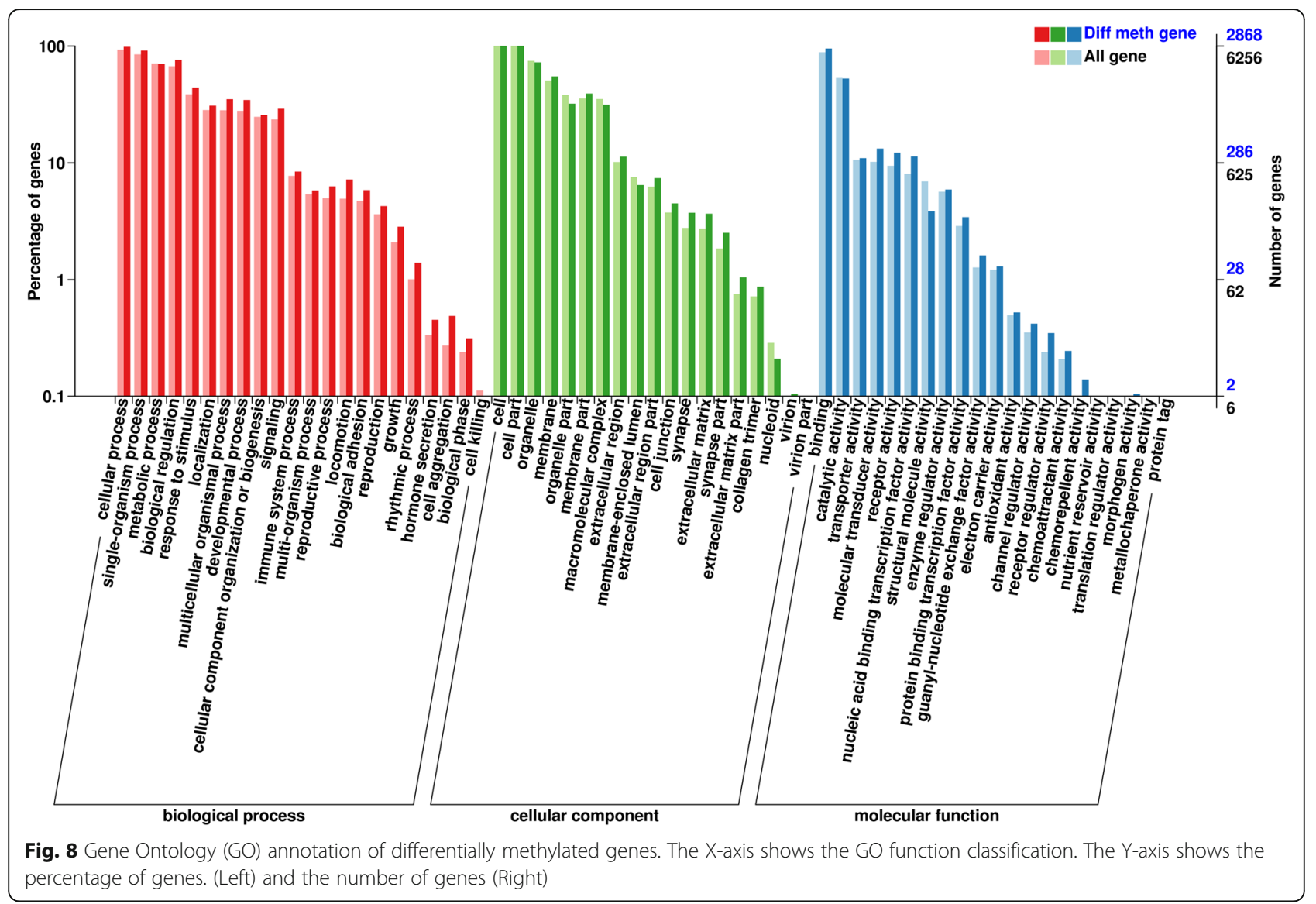

and miRNAs were significantly triggered by SE inoculation $[24,55]$. The methylation variation of rhythmic process- related genes was triggered in chicken following SE inoculation in the current study. The rhythm related process would regulate SE inoculation in different levels. The different response of circadian rhythm between $C$. jejuni inoculation and SE inoculation need to be further studied. The immune system may correlate with the metabolic system involved in regulating SE inoculation. Interestingly, the differentially methylated genes were correlated with immune process, metabolic process and rhythmic process in the current study. It has been reported that circadian clocks, metabolism and immune process are inextricably intertwined $[56,57]$. There may exist an interaction among the three processes in the chicken inoculated with SE. However, the detailed mechanisms need to be further studied.

Wnt signaling pathway is involved in the development, cell differentiation and disease pathophysiology [58], and was significantly altered in chicken cecum at the day 4 after Salmonella infection [59]. Salmonella activates the Wnt/b-catenin signaling pathway to regulate stem cells [60]. Wnt ligands regulate multiple aspects of intestinal pathophysiology. TGF- $\beta$ plays a role in the regulation of inflammation with $\mathrm{T}$ cells being a key target [61]. The
TGF- $\beta$ signaling pathway is significantly changed in the chicken cecum at day 4 post $S$. Enteritidis infection [59]. mTOR is a serine/threonine kinase that plays a role in cell growth and metabolism by sensing environmental cues, including when nutrients are in abundance and when immune cells are in metabolically demanding situations [62, 63]. mTOR is a sensor and regulator of immunometabolic changes during Salmonella infection in the chicken [59]. The enriched Wnt signaling pathway, TGF- $\beta$ signaling pathway and mTOR signaling pathway may indicate that SE inoculation would affect the chicken immune and metabolism through altering gene DNA methylation in related signaling pathways.

$H O X$ genes, a conserved gene family, play crucial roles in embryonic development and is involved in the reproduction and development of cells [64]. HOX genes control Wnt/ßcatenin pathway during axis elongation [65]. The immune function of $H O X$ genes has been reported in cancer [66]. HOXB13, HOXA10 and HOXA1 genes are hyper-methylated in breast cancer patients [67]. HOXA5 gene plays a role in lung organogenesis, digestive tract morphogenesis, thyroid and mammary glands development, ovary homeostasis and tumor predisposition and progression [68, 69]. HOXA5 is modulated by epigenetic mechanism, the methylation level of 


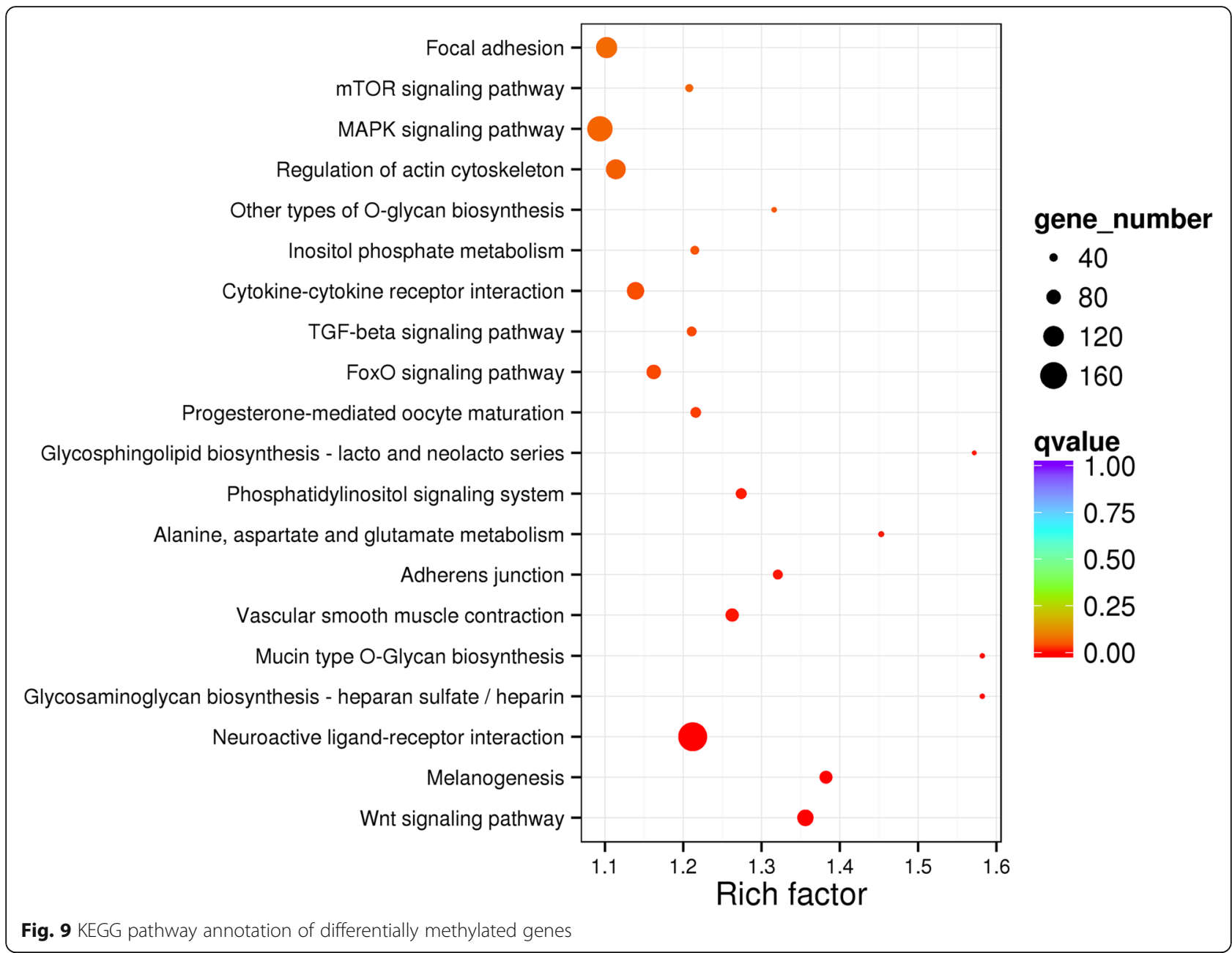

HOXA5 gene promoter is higher in adult compared to fetus in various somatic tissues [64]. HOXC10 plays an important role in growth and reproduction regulation in Jinghai Yellow chicken [70]. HOXB7 gene in chronic lymphocytic leukemia is hypermethylated [71] and represses Death-Associated Protein Kinase 1 gene expression [72]. In the current study, the DMC was detected in 37 genes in $H O X$ gene family, 8 of those genes had higher density than 0.005 and distributed on both Chr2 and Chr7. We speculated the methylation of $H O X$ genes regulated SE inoculation in chicken.

Both miRNA and DNA methylation are important factors to regulate gene expression. DNA methylation can regulate miRNA expression during tumorigenesis [73]. It has been reported that one-third of miRNA promoters are hypermethylated in breast cancer cell lines [74]. Mir129-2 and mir-663a are highly methylated in human urothelial carcinoma [75]. Methylation of miR-9 and miR-17-5p are biomarkers for cancer [76, 77]. Methylation-sensitive mir-345 plays a role of antineoplastic as a growth inhibitor in the development of colorectal cancer [78]. Li et al. found that the promoter regions of miRNAs in the chicken were highly methylated [25], which was consistent with the current results. The hypermethylation in upstream region of gga-miR130b-3p gene contributed to its repressed expression in tumorous tissues [79]. In the current study, miRNA has the most density DMCs among all genes. These findings indicated that miRNAs were sensitive to DNA methylation responding to SE inoculation in chicken. The tRNA modifications affect all aspects of tRNA biology including decoding and charging efficiency and fidelity, in vivo stability, and intracellular localization [80]. Methylation level of tRNA in Escherichia coli and Salmonella sensitize these bacteria to antibiotics [81]. The DMC of 6 tRNAs was higher than 0.10 in the current study. We respected those methylated miRNAs and tRNAs could be referred as a biomaker of SE infection in chicken.

\section{Conclusions}

In conclusion, the cecum genome-wide methylation profile of Jining Bairi chicken following SE inoculation was studied through the whole genome bisulfite sequencing. SE inoculation promoted the genome-wide methylation 
Table 4 The methylation level of validated genes between WGBS and BSP method

\begin{tabular}{|c|c|c|c|c|c|c|}
\hline \multirow{2}{*}{$\begin{array}{l}\text { Gene } \\
\text { name }\end{array}$} & \multirow[t]{2}{*}{ Location } & \multirow{2}{*}{$\begin{array}{l}\text { Meth } \\
\text { direction } \\
\text { in WGBS }\end{array}$} & \multicolumn{3}{|l|}{ BSP } & \multirow{2}{*}{$\begin{array}{l}P \\
\text { value }\end{array}$} \\
\hline & & & Inoculated group & Control group & Difference/ meth_direction & \\
\hline \multirow[t]{2}{*}{ HOXA3 } & Chr2:32659632 & Hypo- & 0.4 & 0.6 & -0.2 & 0.212 \\
\hline & Chr2:32659658 & Hyper- & 0.7 & 0.2 & 0.5 & 0.035 \\
\hline \multirow[t]{4}{*}{ HOXD12 } & Chr7:16384244 & Hyper- & 1 & 0.2 & 0.7 & 0.027 \\
\hline & Chr7:16384255 & Hyper- & 0.7 & 0.4 & 0.3 & 0.113 \\
\hline & Chr7:16384275 & Hyper- & 0.5 & 0 & 0.5 & 0.046 \\
\hline & Chr7:16384301 & Hyper- & 0.8 & 0 & 0.8 & 0.027 \\
\hline \multirow[t]{2}{*}{ DNAH7 } & Chr7:9749766 & Hypo- & 0.4 & 0.8 & -0.4 & 0.051 \\
\hline & Chr7:9750310 & Hyper- & 0.8 & 0.2 & 0.6 & 0.011 \\
\hline \multirow[t]{3}{*}{ NPAT } & Chr1:180358709 & Нyро- & 1 & 0.7 & 0.3 & 0.104 \\
\hline & Chr1:180358843 & Hypo- & 0.6 & 0.9 & -0.3 & 0.067 \\
\hline & Chr1:180358844 & Hyper- & 0.9 & 0.5 & 0.4 & 0.041 \\
\hline \multirow[t]{3}{*}{ MTR } & Chr3:37701958 & Hyper- & 0.7 & 0.2 & 0.5 & 0.039 \\
\hline & Chr3:37702200 & Hyper- & 0.6 & 0.1 & 0.5 & 0.042 \\
\hline & Chr3:37702201 & Hyper- & 0.7 & 0 & 0.7 & 0.014 \\
\hline \multirow[t]{2}{*}{ ZFHX3 } & Chr11:19406308 & Нypo- & 0.2 & 0.5 & -0.3 & 0.169 \\
\hline & Chr11:19406309 & Нypo- & 0.3 & 0.7 & -0.4 & 0.047 \\
\hline
\end{tabular}

level in Jining Bairi chicken. SE inoculation would trigger the aberrant methylation of genes in Wnt signaling pathway, mTOR signaling pathway, immune and metabolism related functional terms. Methylation of miRNA and $H O X$ gene family may play roles in the epigenetic regulation responding to SE inoculation in chicken. Results herein would pave the foundation for understanding the methylation regulation mechanism of chicken in the response of SE inoculation.

\section{Methods}

\section{Animal and sample collection}

Jining Bairi chicken, a China local chicken breed with ability of disease and stress resistance, was used in the current study and provided by Shandong Bairi Chicken Breeding Co., Ltd. (Shandong, China). The S. Enteritidis strain (CVCC3377) used in the current study was purchased from the China Veterinary Culture Collection Center (Beijing, China). The animal trial was performed as described previously [82]. In brief, 168 two-day old SE negative Jining Bairi chickens with similar body weight (28.46 g-30.41 g) were randomly divided into two groups and raised in two separated isolators with the same condition. Each chicken in the inoculated group was orally inoculated with $0.3 \mathrm{ml} 10^{9}$ colony-forming units ( $\left.\mathrm{cfu}\right) / \mathrm{ml}$ SE inoculant, and each chicken in the control group inoculated with the same amount of sterile phosphate buffer saline (PBS). Twelve chickens from each of the inoculated group and control group were euthanized by cervical dislocation for sample collection at 1, 3, 7, 14,
21,28 , and 35 days post inoculation (dpi). The cecum samples were frozen in liquid nitrogen and stored at $80^{\circ} \mathrm{C}$ until further RNA isolation. All animal procedures were approved by Shandong Agricultural University Animal Care and Use Committee.

\section{Genomic DNA extraction and DNA library construction}

Three individual cecum samples from each of inoculated and control groups at $3 \mathrm{dpi}$ were selected for genomic DNA extraction based on our previous study [51]. In total, 6 genomic DNA samples were extracted using TIANamp Genomic DNA Kit (Tiangen, Beijing, China) following the manufacturer's instructions and stored at $-80^{\circ} \mathrm{C}$ until further use. The concentration and quality of DNA sample was evaluated using DS-11 Spectrophotometer (DeNovix, US) and gel electrophoresis, respectively. Three genomic DNA samples in each of inoculated and control groups were mixed with equal amount to generate one pooled sample for sequencing. The DNA samples were sheared with Covaris ultrasonicator (Life Technology, US). The fragmented DNA was purified using AMPure XP beads and end repaired. After end repair and adenylation, cytosine-methylated barcodes were then ligated to sonicated DNA. Subsequently, $100-300 \mathrm{bp}$ insert size targets were purified by $2 \%$ agarose gel electrophoresis. Bisulfite conversion was conducted using the EZ DNA Methylation-Gold Kit (Zymo Research, Irvine, CA, USA). The final libraries were generated by PCR amplification and then analyzed by an Agilent 2100 Bioanalyzer (Agilent Technology, 
Table 5 Primer sequences of genes selected for validation by BSP

\begin{tabular}{llll}
\hline Gene ID & Gene symbol & Primer sequences(5'-3') & Product Length (bp) \\
\hline ENSGALG00000027925 & HOXA3 & F: TGAAGTAAAGGAAGTTGTTGGGGT & 431 \\
ENSGALG00000009274 & R: AAAAAATCATCATACCCTACCCTT & 325 \\
ENSGALG00000007841 & F: AAGAGGAAAGATGTAGGTAGAGGTAATTT & 571 \\
ENSGALG00000017162 & R: AATAAAACACCAAAACAAACCTACAACAAA & 772 \\
ENSGALG00000014464 & F: GGGTTTTAGTATAGGAGAGATGGGGG & R: CACACTTAAATTACTCCTAAACCCATACC & 781 \\
ENSGALG00000000713 & F: AGTAGATGTAGGAAAAGAATAGGTTG & R: AACCACAAAATCCTTAAATCTAAACAC & 794 \\
& MTR & F: AAAGTAGGTTGTATGAGGTGTAGGGTG & 7 : CACTACAATTCACAAACAAAAATACTTCAT \\
\hline
\end{tabular}

US) and quantified by QRT-PCR using QPCR NGS Library Quantification Kit (Agilent, Santa Clara, CA, USA). The constructed libraries were sequenced using Illumina HiSeq 4000 (Illumina, San Diego, CA, USA) by Biomarker Technology Co., Ltd. (Beijing, China).

DNA methylation sequencing data alignment and process The data alignment and process was conducted as described previously [83]. The raw data were preprocessed by removing low quality reads and containing adapters. The clean reads were aligned with the chicken reference genome (Gallus gallus 5.0 ) by Bismark software [84]. The methylation level of single base was then calculated by the ratio of the number of methylated reads to the sum of total reads covering the locus. Methylated locus was determined with the criteria of coverage depth $>4$ and FDR $<0.05$ [84].

The genome coverage of the CG, CHG and $\mathrm{CHH}$ sites under different sequencing depths, distribution of clean reads in different CG density regions was analyzed using Bismark and MOABS software [85]. The genome coverage of the CG, CHG and $\mathrm{CHH}$ sites in every chromosome and different genome components including promoter, gene body, downstream was also analyzed. The differentially methylated regions (DMR) detection between the control and inoculated groups was based on hidden Markov models using Bisulfighter [85]. The methylation levels of DMRs were then calculated with default parameters. Subsequently, DMRs were annotated with the chicken genome. Gene overlapped with at least one DMR was defined as differentially methylated gene (DMG). As a next step, genes that have hypo- or hypermethylated CpGs within the gene were defined as hypoor hyper-methylated genes. The GO enrichment and KEGG pathway analysis was conducted for differentially methylated genes using the BLAST Functional
Annotation Tool [86-88]. $P<0.05$ was considered as significance.

\section{Bisulfite sequencing PCR analysis (BSP)}

The specific primers for BSP were designed using MethPrimer 2.0 (http://www.urogene.org/methprimer2) and listed in Table 5. One microgram DNA from three sample in each group was treated using the EZ DNA Methylation-Gold Kit (Zymo Research, Irvine, CA, USA) according to the manufacturer's instructions respectively. The converted DNA was amplified using Ex Taq Hot Start Version (Takara Bio Inc., Otsu, Japan). The PCR product was cloned into the pMD18-T vector (Takara Bio Inc., Otsu, Japan). Twenty clones for each gene were sequenced using ABI3730XL DNA Analyzer (Applied Biosystems, CA, USA). All the sequences were analyzed using BiQ Analyzer [89]. The methylation difference in each site between inoculated and control groups was analyzed through t-test.

\section{Supplementary Information}

The online version contains supplementary material available at https://doi. org/10.1186/s12864-020-07174-w.

Additional file 1: Supplementary Table S1. The top 30 Genes with high DMC density.

Additional file 2: Supplementary Table S2. The DMC density of the HOX genes.

Additional file 3: Supplementary Table S3. The differentially methylated genes in each GO terms.

Additional file 4: Supplementary Table S4.The differentially methylated genes in two pathways.

\section{Abbreviations}

SE: Salmonella enterica serovar Enteritidis; WGBS: Whole genome bisulfite sequencing; TLR: Toll-like receptor; IL: Interleukin; TSS: Transcription start site; PBS: Phosphate buffer saline; BSP: Bisulfite sequencing PCR;

DMR: Differentially methylated region; DMC: Differentially methylated cytosine; GO: Gene Ontology; BP: Biological process; MF: Molecular function; CC: Cellular component; COG: Clusters of Orthologous Group 


\section{Acknowledgements}

We thank Hao Zhang for providing the Jining Bairi chicken used in the current study.

\section{Authors' contributions}

YW drafted the manuscript. LL1 did animal trial and drafted the manuscript. $M L$ and LL2 performed the experiment and analyzed the data. PS, HT and XF analyzed the data and revised the manuscript. $\mathrm{XL}$ designed the experiment and revised the manuscript. All authors have read and approved the manuscript.

\section{Funding}

This work was supported by the National Natural Science Foundation of China (31872343), Shandong Modern Agricultural Industry \& Technology System (SDAIT-11-02), Shandong Province Agricultural Seed Project (2017LZN007), Funds of Shandong "Double Tops" Program (SYL2017YSTD12), Shandong Provincial Natural Science Foundation (ZR2018MC026), and Rizhao Key Research and Development projects of Shandong Province (2019CXZX1108). The funders had no role in study design, data collection and analysis, decision to publish, or preparation of the manuscript.

\section{Availability of data and materials}

The datasets generated and/or analyzed during the current study are available in the Sequence Read Archive repository with accession number of PRJNA668639. Accession numbers in Table 5, Table S2 and Table S4 were obtained from the Ensemble genome browser database (http://asia.ensembl. org/index.html).

\section{Ethics approval and consent to participate}

All animal procedures were approved by Shandong Agricultural University Animal Care and Use Committee.

\section{Consent for publication}

Not applicable.

\section{Competing interests}

The authors declare that they have no competing interests.

\section{Author details}

'College of Animal Science and Technology, Shandong Provincial Key Laboratory of Animal Biotechnology and Disease Control and Prevention, Shandong Agricultural University, Tai'an 271018, Shandong, China. ${ }^{2}$ College of Life Science, Shandong Agricultural University, Tai'an 271018, Shandong, China.

Received: 30 March 2020 Accepted: 21 October 2020

Published online: 23 November 2020

\section{References}

1. Chappell L, Kaiser P, Barrow P, Jones MA, Johnston C, Wigley P. The immunobiology of avian systemic salmonellosis. Vet Immunol Immunopathol. 2009;128(1-3):53-9.

2. Ulloa J, Gonzalez M, Hernandez C, Villanueva MP, Fernandez H. Salmonella Enteritidis in chicken carcasses and giblets in southern Chile. J Infect Dev Ctries. 2010;4(2):107-9.

3. Guibourdenche M, Roggentin P, Mikoleit M, Fields PI, Bockemühl J, Grimont PAD, Weill F-X. Supplement 2003-2007 (no. 47) to the white-Kauffmann-Le Minor scheme. Res Microbiol. 2010;161(1):26-9.

4. Gomez TM, Motarjemi Y, Miyagawa S, Käferstein FK, Stöhr K. Foodborne salmonellosis. World Health Stat Q. 1997;50(1-2):81-9.

5. Bosilevac JM, Guerini MN, Kalchayanand N, Koohmaraie M. Prevalence and characterization of salmonellae in commercial ground beef in the United States. Appl Environ Microbiol. 2009;75(7):1892.

6. Foley SL, Lynne AM. Food animal-associated Salmonella challenges: pathogenicity and antimicrobial resistance. J Anim Sci. 2008;86(14 Suppl): 173-87.

7. Scallan E, Hoekstra RM, Angulo FJ, Tauxe RV, Widdowson MA, Roy SL, Jones $\mathrm{JL}$, Griffin PM. Foodborne illness acquired in the United States--major pathogens. Emerg Infect Dis. 2011;17(1):7-15.
8. Authority EFS. The European Union summary report on trends and sources of zoonoses, zoonotic agents and food-borne outbreaks in 2016. EFSA J. 2017;15(12):e05077.

9. Velasco G, Hubé F, Jm R, Neuillet D, Philippe C, Bouzinba-Segard H, Galvani A, Viegas-Péquignot E, Francastel C, Groudine MT. Dnmt3b recruitment through E2F6 transcriptional repressor mediates germ-line gene silencing in murine somatic tissues. Proc Natl Acad Sci U S A. 2010;107(20):9281-6.

10. Gilsbach R, Preissl S, Gruning B, Schnick T, Burger L, Benes V, Wurch A, Bonisch U, Gunther S, Backofen R. Dynamic DNA methylation orchestrates cardiomyocyte development, maturation and disease. Nat Commun. 2014; 5(1):5288.

11. Zhang X, Yazaki J, Sundaresan A, Cokus SJ, Chan SWL, Chen H, Henderson IR, Shinn P, Pellegrini M, Jacobsen SE. Genome-wide high-resolution mapping and functional analysis of DNA methylation in Arabidopsis. Cell. 2006;126(6):1189-201.

12. Tran RK, Zilberman D, de Bustos C, Ditt RF, Henikoff JG, Lindroth AM, Delrow J, Boyle T, Kwong S, Bryson TD, et al. Chromatin and siRNA pathways cooperate to maintain DNA methylation of small transposable elements in Arabidopsis. Genome Biol. 2005;6(11):R90.

13. Zilberman D, Gehring M, Tran RK, Ballinger T, Henikoff S. Genome-wide analysis of Arabidopsis thaliana DNA methylation uncovers an interdependence between methylation and transcription. Nat Genet. 2007; 39(1):61-9.

14. Simmen MW, Leitgeb S, Charlton J, Jones SJM, Harris B, Clark VH, Bird A. Nonmethylated transposable elements and methylated genes in a chordate genome. Science. 1999;283(5405):1164-7.

15. Brenet $F$, Moh M, Funk P, Feierstein E, Viale AJ, Socci ND, Scandura JM. DNA methylation of the first exon is tightly linked to transcriptional silencing. PLoS One. 2011;6(1):e14524.

16. Kass SU, Pruss D, Wolffe AP. How does DNA methylation repress transcription? Trends Genet. 1997;13(11):444-9.

17. Luan DQ, Chang GB, Sheng ZW, Zhang Y, Zhou W, Li ZZ, Liu Y, Chen GH. Analysis of gene expression responses to a Salmonella infection in Rugao chicken intestine using GeneChips. Asian Australas J Anim Sci. 2012;25(2): $278-85$.

18. Zhen W, Shao Y, Gong X, Wu Y, Geng Y, Wang Z, Guo Y. Effect of dietary Bacillus coagulans supplementation on growth performance and immune responses of broiler chickens challenged by Salmonella enteritidis. Poult Sci. 2018;97(8):2654-66.

19. Ciraci C, Tuggle CK, Wannemuehler MJ, Nettleton D, Lamont SJ. Unique genome-wide transcriptome profiles of chicken macrophages exposed to Salmonella-derived endotoxin. BMC Genomics. 2010;11:545.

20. Wu G, Liu L, Qi Y, Sun Y, Yang N, Xu G, Zhou H, Li X. Splenic gene expression profiling in white Leghorn layer inoculated with the Salmonella enterica serovar Enteritidis. Anim Genet. 2015;46(6):617-26.

21. Su J, Wang Y, Xing X, Liu J, Zhang Y. Genome-wide analysis of DNA methylation in bovine placentas. BMC Genomics. 2014;15:12.

22. Wang YY, Sun LX, Zhu JJ, Zhao Y, Wang H, Liu HJ, Ji XS. Epigenetic control of cyp19a1a expression is critical for high temperature induced Nile tilapia masculinization. J Therm Biol. 2017;69:76-84.

23. Han B, Li W, Chen Z, Xu Q, Luo J, Shi Y, Li X, Yan X, Zhang J. Variation of DNA Methylome of Zebrafish cells under cold pressure. PLoS One. 2016; 11(8):e0160358

24. Wu G, Qi Y, Liu X, Yang N, Xu G, Liu L, Li X. Cecal MicroRNAome response to Salmonella enterica serovar Enteritidis infection in white Leghorn layer. BMC Genomics. 2017;18(1):77.

25. Li J, Li R, Wang Y, Hu X, Zhao Y, Li L, Feng C, Gu X, Liang F, Lamont SJ. Genome-wide DNA methylome variation in two genetically distinct chicken lines using MethylC-seq. BMC Genomics. 2015;16(1):851.

26. Weber M, Davies JJ, Wittig D, Oakeley EJ, Haase M, Lam WL, Schubeler D. Chromosome-wide and promoter-specific analyses identify sites of differential DNA methylation in normal and transformed human cells. Nat Genet. 2005;37(8):853-62.

27. Li Y, Ding X, Wang X, He T, Zhang H, Yang L, Wang T, Chen L, Gai J, Yang S. Genome-wide comparative analysis of DNA methylation between soybean cytoplasmic male-sterile line NJCMS5A and its maintainer NJCMS5B. BMC Genomics. 2017;18(1):596.

28. Sati S, Tanwar VS, Kumar KA, Patowary A, Jain V, Ghosh S, Ahmad S, Singh M, Reddy SU, Chandak GR, et al. High resolution methylome map of rat indicates role of intragenic DNA methylation in identification of coding region. PLoS One. 2012;7(2):e31621. 
29. Yan H, Kikuchi S, Neumann P, Zhang W, Wu Y, Chen F, Jiang J. Genomewide mapping of cytosine methylation revealed dynamic DNA methylation patterns associated with genes and centromeres in rice. Plant J. 2010;63(3): 353-65.

30. Li Q, Li N, Hu X, Li J, Du Z, Chen L, Yin G, Duan J, Zhang H, Zhao Y, et al. Genome-wide mapping of DNA methylation in chicken. PLoS One. 2011 6(5):e19428

31. Suarez-Alvarez B, Rodriguez RM, Fraga MF, López-Larrea C. DNA methylation: a promising landscape for immune system-related diseases. Trends Genet Tig. 2012;28(10):506-14.

32. Xu H, Zhu X, Hu Y, Li Z, Zhang X, Nie Q, Nolan LK, Lamont SJ. DNA methylome in spleen of avian pathogenic Escherichia coli-challenged broilers and integration with mRNA expression. Sci Rep. 2014;4:4299.

33. Wang F, Li J, Li Q, Liu R, Zheng M, Wang Q, Wen J, Zhao G. Changes of host DNA methylation in domestic chickens infected with Salmonella enterica. J Genet. 2017;96(4):1-6.

34. Gou Z, Liu R, Zhao G, Zheng M, Li P, Wang H, Zhu Y, Chen J, Wen J. Epigenetic modification of TLRs in leukocytes is associated with increased susceptibility to Salmonella enteritidis in chickens. PLoS One. 2012;7(3): e33627.

35. Li $X$, Zhang $P$, Jiang $X$, Du H, Yang $C$, Zhang $Z$, Men $S$, Zhang $Z$, Jiang $W$, Wang $\mathrm{H}$. Differences in expression of genes in the MyD88 and TRIF signalling pathways and methylation of TLR4 and TRIF in Tibetan chickens and DaHeng S03 chickens infected with Salmonella enterica serovar enteritidis. Vet Immunol Immunopathol. 2017;189:28-35.

36. Wang S, Liu L, Wu G, Liu X, Tang H, Li X. The effect of Salmonella enteritis infection on chicken cecal genomic DNA methylation. Chin J Vet Sci. 2016; 36(2):271-80.

37. Li Q, Hermanson PJ, Springer NM. Detection of DNA methylation by wholegenome bisulfite sequencing. Methods Mol Biol. 1676;2018:185-96.

38. Habibi E, Brinkman AB, Arand J, Kroeze LI, Kerstens HH, Matarese F, Lepikhov K, Gut M, Brun-Heath I, Hubner NC, et al. Whole-genome bisulfite sequencing of two distinct interconvertible DNA methylomes of mouse embryonic stem cells. Cell Stem Cell. 2013;13(3):360-9.

39. Zhong S, Fei Z, Chen YR, Zheng Y, Huang M, Vrebalov J, McQuinn R, Gapper $\mathrm{N}$, Liu B, Xiang J, et al. Single-base resolution methylomes of tomato fruit development reveal epigenome modifications associated with ripening. Nat Biotechnol. 2013;31(2):154-9.

40. Kretzmer H, Bernhart SH, Wang W, Haake A, Weniger MA, Bergmann AK, Betts MJ, Carrillo-de-Santa-Pau E, Doose G, Gutwein J, et al. DNA methylome analysis in Burkitt and follicular lymphomas identifies differentially methylated regions linked to somatic mutation and transcriptional control. Nat Genet. 2015;47(11):1316-25.

41. Smith ZD, Meissner A. DNA methylation: roles in mammalian development. Nat Rev Genet. 2013;14(3):204-20.

42. Ball MP, Li JB, Gao Y, Lee J, Leproust EM, Park I, Xie B, Daley GQ, Church GM Targeted and genome-scale strategies reveal gene-body methylation signatures in human cells. Nat Biotechnol. 2009;27(4):361-8.

43. Yang C, Ye J, Li X, Gao X, Zhang K, Luo L, Ding J, Zhang Y, Li Y, Cao H, et al. DNA methylation patterns in the hypothalamus of female pubertal goats. PLoS One. 2016;11(10):e0165327.

44. Lokk K, Modhukur V, Rajashekar B, Martens K, Magi R, Kolde R, Koltsina M, Nilsson TK, Vilo J, Salumets A, et al. Erratum to: DNA methylome profiling of human tissues identifies global and tissue-specific methylation patterns. Genome Biol. 2016;17(1):224

45. Jaroslav J, Vazganush G, EMR H, Kimie K, Rong H, Woonbok C, Yue L, Nianxiang Z, Shoudan L, KH M. Aberrant DNA Methylation Is Associated with Disease Progression, Resistance to Imatinib and Shortened Survival in Chronic Myelogenous Leukemia. PLoS One. 2011;6(7):e22110.

46. Henderson IR, Jacobsen SE. Epigenetic inheritance in plants. Nature. 2007; 447(7143):418-24.

47. Luo J, Yu Y, Chang S, Tian F, Zhang H, Song J. DNA methylation fluctuation induced by virus infection differs between MD-resistant and -susceptible chickens. Front Genet. 2012;3:20.

48. Wang XJ, Liu L, Zhao JP, Jiao H, Lin H. Stress impairs the reproduction of laying hens: an involvement of energy. Worlds Poult Sci J. 2017:73(4):845-56.

49. Yang J, Lei L, Ardashir S, Wang Y, Li C, Jiao H, Hai L, Song Z, Wu SB. Effects of Corticosterone and Dietary Energy on Immune Function of Broiler Chickens. PLoS One. 2015;10(3):e0119750.

50. Li X, Swaggerty CL, Kogut MH, Chiang HI, Wang Y, Genovese KJ, He H, Zhou $\mathrm{H}$. Gene expression profiling of the local cecal response of genetic chicken lines that differ in their susceptibility to campylobacter jejuni colonization. PLoS One. 2010;5(7):e11827.

51. Wang Y, Miao X, Li H, Su P, Lin L, Liu L, Li X. The correlated expression of immune and energy metabolism related genes in the response to Salmonella enterica serovar Enteritidis inoculation in chicken. BMC Vet Res. 2020;16(1):257.

52. Bruggemann $M$, Gromes A, Poss $M$, Schmidt D, Klumper N, Tolkach $Y$, Dietrich D, Kristiansen G, Muller SC, Ellinger J. Systematic analysis of the expression of the mitochondrial ATP synthase (complex V) subunits in clear cell renal cell carcinoma. Transl Oncol. 2017;10(4):661-8.

53. Lin Z, Hegarty JP, Cappel JA, Yu W, Chen X, Faber PW, Wang Y, Kelly AA, Poritz LS, Peterson BZ. Identification of disease-associated DNA methylation in intestinal tissues from patients with inflammatory bowel disease. Clin Genet. 2011:80(1):59-67.

54. Qiu P, Jiang J, Liu Z, Cai Y, Huang T, Wang Y, Liu Q, Nie Y, Liu F, Cheng J. BMAL1 knockout macaque monkeys display reduced sleep and psychiatric disorders. Natl Sci Rev. 2019;6(1):87-100

55. Zheng L, Liu L, Lin L, Tang H, Fan X, Lin H, Li X. Cecal CircRNAs are associated with the response to Salmonella Enterica Serovar Enteritidis inoculation in the chicken. Front Immunol. 2019:10:1186.

56. Leone V, Gibbons SM, Martinez K, Hutchison AL, Huang EY, Cham CM, Pierre JF, Heneghan AF, Nadimpalli A, Hubert N. Effects of diurnal variation of Gut microbes and high-fat feeding on host circadian Clock function and metabolism. Cell Host Microbe. 2015;17(5):681-9.

57. Liu X, Liu L, Zhang M, Yang N, Li X. Messenger RNA expression of chicken CLOCK gene in the response to campylobacter jejuni inoculation. Poult Sci. 2015:94(9):2124-30.

58. Clevers H, Nusse R. Wnt/ $\beta$-catenin signaling and disease. Cell. 2012;149(6): 1192-205.

59. Kogut MH, Arsenault RJ. A role for the non-canonical Wnt- $\beta$-catenin and TGF- $\beta$ signaling pathways in the induction of tolerance during the establishment of a Salmonella enterica Serovar Enteritidis persistent Cecal infection in chickens. Front Vet Sci. 2015;2:33.

60. Liu X, Lu R, Wu S, Sun J. Salmonella regulation of intestinal stem cells through the Wnt/B-catenin pathway. FEBS Lett. 2010;584(5):911-6.

61. Sakaguchi S. Naturally arising CD4+ regulatory t cells for immunologic selftolerance and negative control of immune responses. Annu Rev Immunol. 2004;22(1):531-62.

62. Laplante M, Sabatini DM. mTOR signaling in growth control and disease. Cell. 2012;149(2):274-93.

63. Cobbold SP. The mTOR pathway and integrating immune regulation. Immunology. 2013;140(4):391-8.

64. Sinha $P$, Singh $K$, Sachan M. High resolution methylation analysis of the HoxA5 regulatory region in different somatic tissues of laboratory mouse during development. Gene Expr Patterns. 2017;23-24:59-69.

65. Denans N, limura T, Pourquie O. Hox genes control vertebrate body elongation by collinear Wnt repression. eLife. 2015;4:e04379.

66. Duboule D. Vertebrate Hox genes and proliferation: an alternative pathway to homeosis? Curr Opin Genet Dev. 1995;5(4):525-8.

67. Pilato B, Pinto R, De Summa S, Lambo R, Paradiso A, Tommasi S. HOX gene methylation status analysis in patients with hereditary breast cancer. J Hum Genet. 2013;58(1):51-3.

68. Jeannotte L, Gotti F, Landry-Truchon K. Hoxa5: A Key Player in Development and Disease. J Dev Biol. 2016:4(2):13.

69. Aubin J, Chailler P, Ménard D, Jeannotte L. Loss of Hoxa5 gene function in mice perturbs intestinal maturation. Am J Phys. 1999;277(5):C965-73.

70. Zhang XQ, Dong XL, Ling JJ, Han KP, Zhang T, Wang JY, Wang YJ. Tissue expression and bioinformatics analysis of HOXC10 gene in Jinghai yellow chicken. China Anim Husbandry Vet Med. 2016;43(7):1702-8.

71. Tong WG, Wierda WG, Lin E, Kuang S-Q, Bekele BN, Estrov Z, Wei Y, Yang H, Keating MJ, Garcia-Manero G. Genome-wide DNA methylation profiling of chronic lymphocytic leukemia allows identification of epigenetically repressed molecular pathways with clinical impact. Epigenetics. 2010;5(6):499-508.

72. Raval A, Tanner SM, Byrd JC, Angerman EB, Perko JD, Chen S-S, Br H, Grever MR, Lucas DM, Matkovic JJ. Downregulation of death-associated protein kinase 1 (DAPK1) in chronic lymphocytic leukemia. Cell. 2007;129(5):879-90.

73. Kunej T, Godnic I, Ferdin J, Horvat S, Dovc P, Calin GA. Epigenetic regulation of microRNAs in cancer: an integrated review of literature. Mutat Res. 2011; 717(1-2):77-84

74. Lukas V, Mo-RJ L, SM R, FB W, Christopher S J. miRNA Gene Promoters Are Frequent Targets of Aberrant DNA Methylation in Human Breast Cancer. PLoS One. 2013;8(1):e54398. 
75. Padrao NA, Monteiroreis S, Torresferreira J, Antunes L, Leca L, Montezuma D, Ramalhocarvalho J, Dias PC, Monteiro P, Oliveira J. MicroRNA promoter methylation: a new tool for accurate detection of urothelial carcinoma. Br J Cancer. 2017:116(5):634-9.

76. Minor JS, Wang X, Zhang F, Song Jl, Jimeno A, Wang X, Lu X, Gross ND, Kuleszmartin M, Wang D. Methylation of microRNA-9 is a specific and sensitive biomarker for oral and oropharyngeal squamous cell carcinomas. Oral Oncol. 2012;48(1):73-8.

77. Konno M, Koseki J, Asai A, Yamagata A, Shimamura T, Motooka D, Okuzaki D, Kawamoto K, Mizushima T, Eguchi H. Distinct methylation levels of mature microRNAs in gastrointestinal cancers. Nat Commun. 2019;10(1):3888.

78. Tang JT, Wang JL, Du W, Hong J, Zhao SL, Wang YC, Xiong H, Chen HM, Fang JY. MicroRNA 345, a methylation-sensitive microRNA is involved in cell proliferation and invasion in human colorectal cancer. Carcinogenesis. 2011; 32(8):1207-15

79. Zhao C, Li X, Han B, Qu L, Liu C, Song J, Lian L, Yang N. Gga-miR-130b-3p inhibits MSB1 cell proliferation, migration, invasion, and its downregulation in MD tumor is attributed to hypermethylation. Oncotarget. 2018;9(36): 24187-24198.

80. Zaborske JM, DuMont VL, Wallace EW, Pan T, Aquadro CF, Drummond DA. A nutrient-driven tRNA modification alters translational fidelity and genome-wide protein coding across an animal genus. PLoS Biol. 2014; 12(12):e1002015

81. Masuda I, Matsubara R, Christian T, Rojas ER, Yadavalli SS, Zhang L, Goulian M, Foster $\sqcup$, Huang KC, Hou Y. tRNA methylation is a global determinant of bacterial multi-drug resistance. Cell Syst. 2019;8(4):302.

82. Liu L, Lin L, Zheng L, Tang H, Fan X, Xue N, Li M, Liu M, Li X. Cecal microbiome profile altered by Salmonella enterica, serovar Enteritidis inoculation in chicken. Gut Pathogens. 2018;10(1):34.

83. Liu Z, Han S, Shen X, Wang Y, Yin H. The landscape of DNA methylation associated with the transcriptomic network in layers and broilers generates insight into embryonic muscle development in chicken. Int J Biol Ences. 2019;15(7):1404-18.

84. Krueger F, Andrews S. Bismark: a flexible aligner and methylation caller for bisulfite-Seq applications. Bioinformatics. 2011;27(11):1571-2.

85. Saito Y, Tsuji J, Mituyama T. Bisulfighter: accurate detection of methylated cytosines and differentially methylated regions. Nucleic Acids Res. 2014; 42(6):e45.

86. Ashburner M, Ball CA, Blake JA, Botstein D, Cherry JM. Gene ontology: tool for the unification of biology. Nat Genet. 2000;25(1):25-9.

87. Deng YY, Li JQ, Wu SF, Zhu YP, He FC. Integrated nr database in protein annotation system and its localization. Comput Eng. 2006;32(5):71-2.

88. Bairoch A, Apweiler R. The SWISS-PROT protein sequence database and its supplement TrEMBL in 2000. Nucleic Acids Res. 2000;28(1):45-8.

89. Bock C, Reither S, Mikeska T, Paulsen M, Walter J, Lengauer T. BiQ analyzer: visualization and quality control for DNA methylation data from bisulfite sequencing. Bioinformatics. 2005;21(21):4067-8.

\section{Publisher's Note}

Springer Nature remains neutral with regard to jurisdictional claims in published maps and institutional affiliations.

\section{Ready to submit your research? Choose BMC and benefit from:}

- fast, convenient online submission

- thorough peer review by experienced researchers in your field

- rapid publication on acceptance

- support for research data, including large and complex data types

- gold Open Access which fosters wider collaboration and increased citations

- maximum visibility for your research: over $100 \mathrm{M}$ website views per year

At $\mathrm{BMC}$, research is always in progress.

Learn more biomedcentral.com/submissions 